\title{
Interactive Media in Learning Japanese Language Vocabulary for Vocational School
}

\author{
N. Haristiani \\ Departemen Pendidikan Bahasa Jepang \\ Universitas Pendidikan Indonesia \\ Bandung, Indonesia \\ Email: nuriaharist@upi.edu
}

\author{
R.S. Rahmawati \\ Program Studi Sastra Jepang \\ Universitas Komputer Indonesia (Unikom) \\ Bandung, Indonesia
}

\begin{abstract}
This research aimed to develop a model for an interactive media on Japanese learning and to examine its impact on student ability for remembering Japanese language vocabulary. Different from other methods, this media was user friendly for students who want to learn independently. Further, this interactive media was technology-based and equipped by some features. To confirm the performance of this media, the study was completed with pre-experimental method, one group pretest-posttest design, and questionnaires. The research subjects were tens senior high school students (class $X$ and XI) of national vocational school in Indonesia (i.e. SMK Negeri 1 Cimahi) who take Japanese language as an elective subject. The results of pretest and posttest showed that the use of this interactive media improved student ability on understanding and using Japanese language vocabulary. The questionnaires showed positive responses from students. The media was attractive, easy to be used, and useful for remembering Japanese language vocabulary.
\end{abstract}

Keywords - interactive media, vocabulary, pre-experimental, one group pretest-posttest design.

\section{INTRODUCTION}

Japanese language is widely learned as a foreign language by large number of students around the world [1][2]. The position of Japan as one of powerful countries has been contributed to its significant role in several aspects as well as dissemination of its culture, including language, art, design, technology, fashion and cuisine [2]. These reasons encourage students to learn Japanese language as a foreign language. Students also want to learn Japanese due to its prospect in business requirement, the desire and curiosity, intellectual stimulation, personal challenge, and cultural tolerance [3].

In learning foreign language, including Japanese language, communication skill must be improved [4]. Indeed, this skill must be supported by good mastery of vocabulary as a basic building block for language ability itself. Vocabulary is used for forming larger structures of sentences, paragraphs, and whole texts [5]. However, learning vocabulary in Japanese language is not so simple, especially relating to its complexity in writing and pronounciation [6]. Some teachers use

\author{
D. Sofiani, A.B.D. Nandiyanto \\ Departemen Pendidikan Kimia \\ Universitas Pendidikan Indonesia \\ Bandung, Indonesia \\ Email: nandiyanto@upi.edu
}

conventional methods for teaching Japanese vocabulary. In general, in the conventional teaching method, students are assigned to memorize vocabularies and do some exercises [7]. Although this method has been widely used, this method is not effective because this makes student bored. Indeed, less motivation for learning this language will be found. Thus, an effective teaching method must be found to make students understand vocabulary easier.

To solve the above problems, some researchers have developed media to help and improve ability in Japanese language vocabulary, including: (1) media image picture [8], (2) smart card [9], and (3) the quartet card [10]. Although these media are attractive and enhance student motivation, several limitations are persisted. Specifically, the suggested methods are not user friendly for student that wants to learn independently.

Based on the above limitations, the purpose of this research was to develop an interactive learning media for learning Japanese language vocabulary. This media was technologybased and equipped by some features. Interestingly, the media was displayed with a Flash Player and able to be operated without additional software. Thus, this media can be accessed by students at any time and used independently by running the command buttons.

\section{RESEARCH METHODOLOGY}

\section{A. Research method}

This study was conducted by pre-experiment method, one group pretest-posttest design, and questionnaires. Pretest and posttest design is widely used for measuring the change from experimental treatments in order to assess its impact [11].

\section{B. Subjects}

The target population for this experiment was students in vocational school in Indonesia who take Japanese language as an elective subject. The sample was one group that consisted of 
15 senior high school students (class $\mathrm{X}$ and $\mathrm{XI}$ ) at vocational school (i.e. SMK Negeri 1 Cimahi).

\section{Materials}

The material used in this experiment was an interactive media of Macromedia Flash Software. The media design consisted of opening, content, and cover that were displayed in different stages (worksheet). Opening section is shown in Figure 1. Content section displayed the features that provided in the media, including vocabularies (Figure 2). The vocabularies were arranged based on the themes (i.e., school, house, laboratory, and workshop), goiklopedia (providing the terms and the definition of the problem), problems, and music. The vocabularies in each theme consisted of nouns, adjectives, and verbs. To complete the media, exercises and problems were also added. Detailed appearance of these sections is shown in Figures 3 and 4.

The media was equipped by the commands buttons for operating the media practically. Accessories were also added such as variations of color, motion animation, effects, and icons. All of these accessories were given to support the respond student to the problems. The respond given for the right answer was circle sign, whereas that for the wrong answer was cross sign (see Figure 5). After the test was completed, the media calculated the student score automatically and, subsequently, the student score was displayed (see Figure 6).

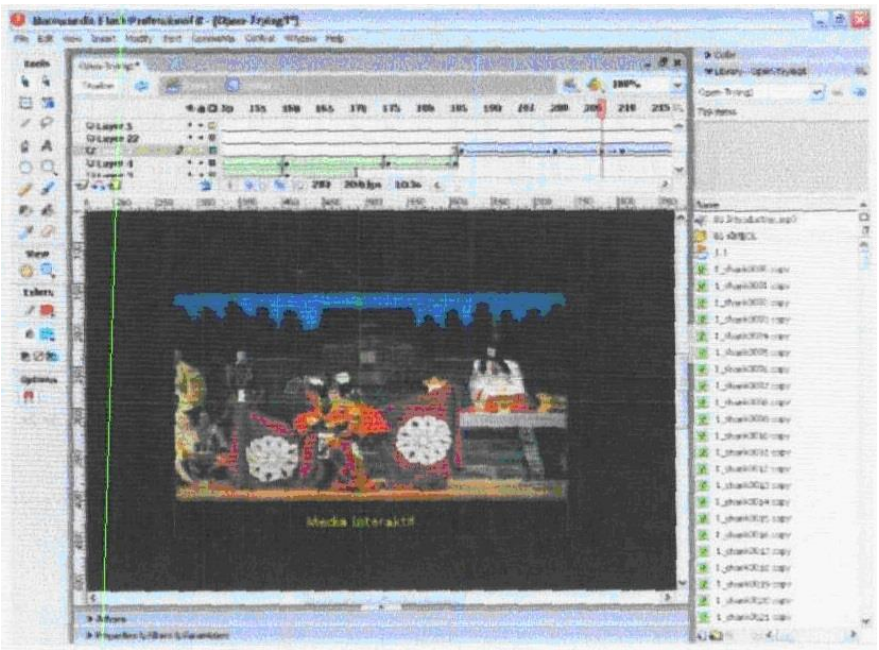

Fig. 1. Appearance of opening display

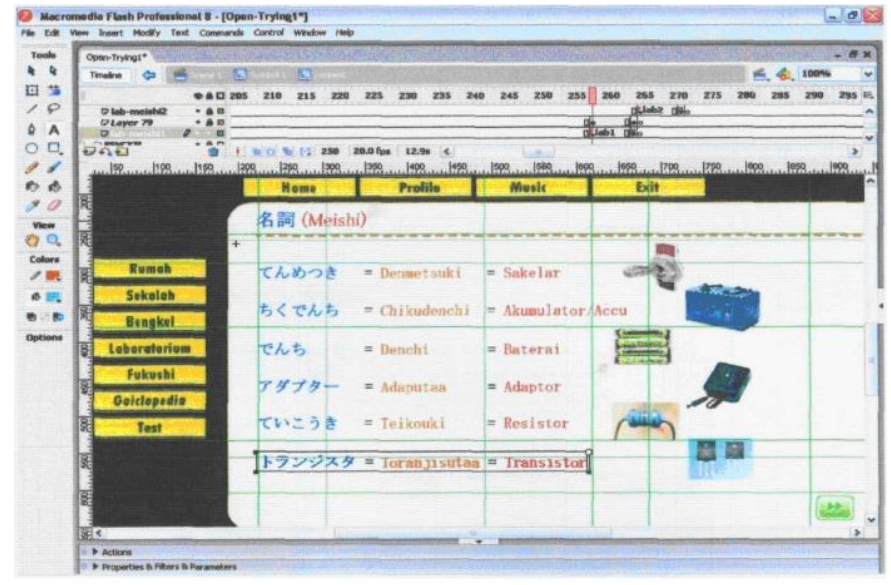

Fig. 2. Example of a vocabulary display

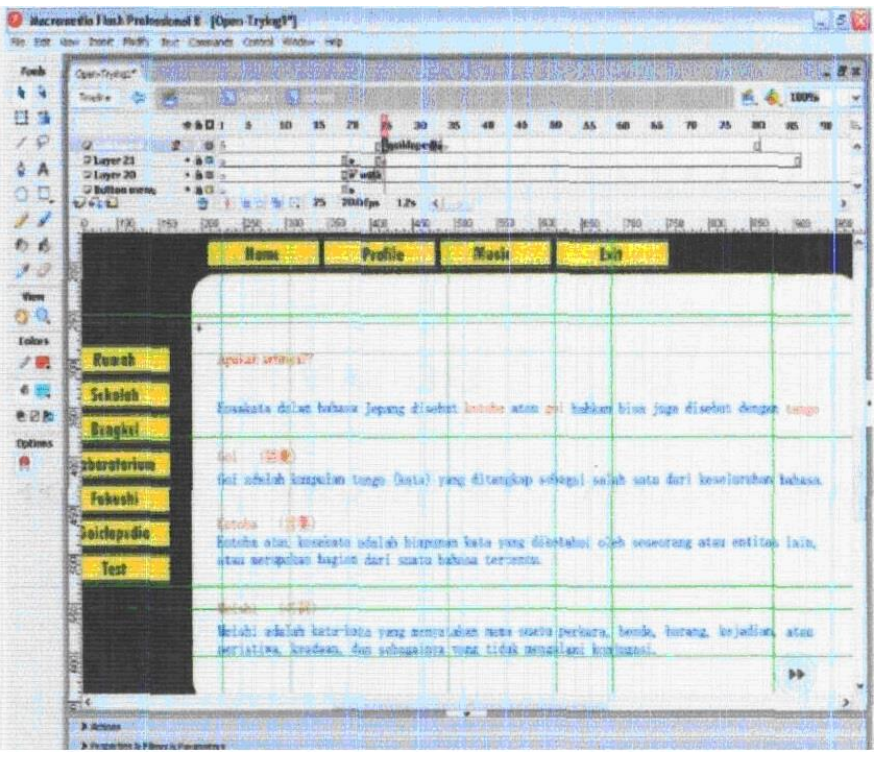

Fig. 3. Goiklopedia display

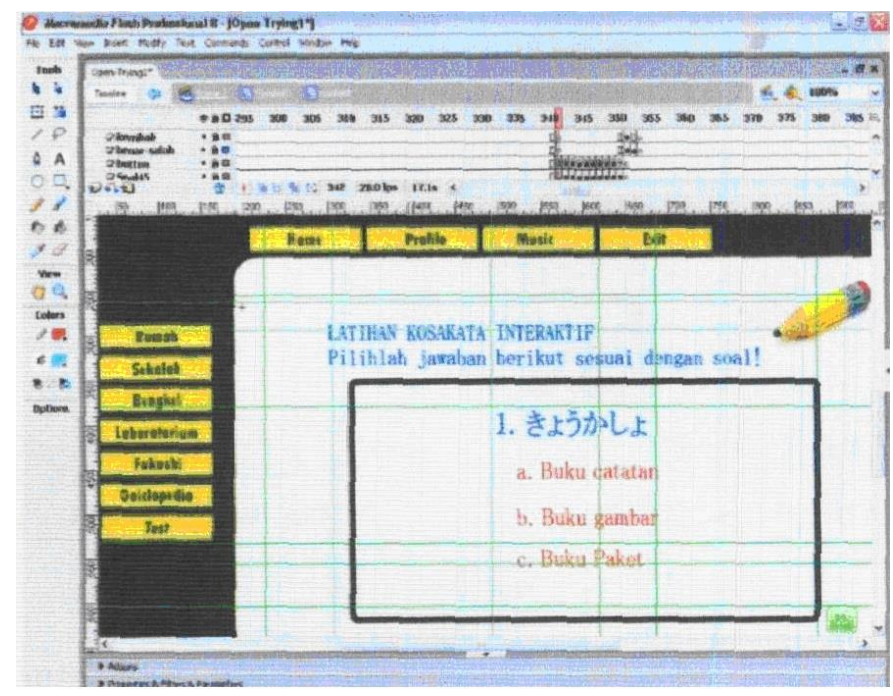

Fig. 4. Example of a test form display 


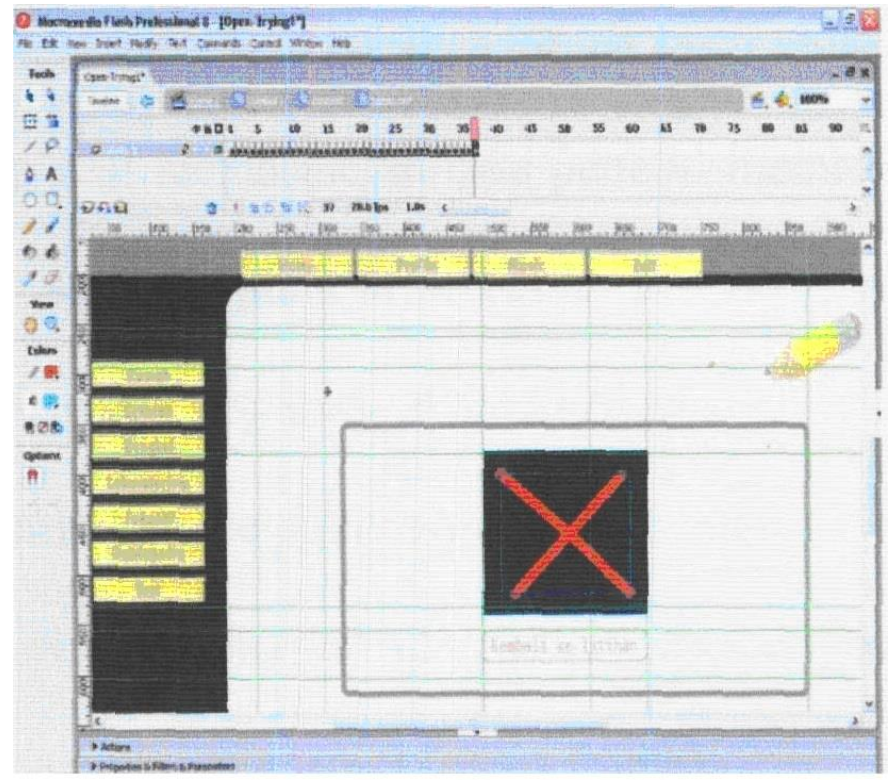

Fig. 5. Appearance of responding answer

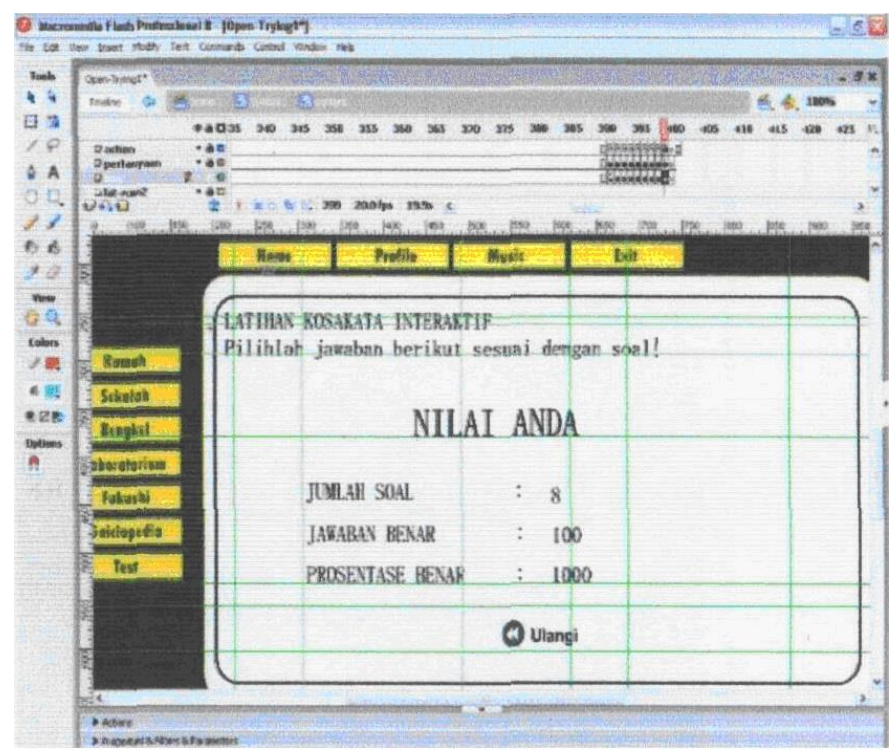

Fig. 6. Display of score test

\section{Research Procedures}

The present research was conducted by doing four-class meetings. In the first meeting, students were given pretest of Japanese vocabularies to reduce error variance [11]. In the second meeting, students were given a brief orientation about the operation of this interactive media and its features. Then, this media was used to learn Japanese language vocabulary. In this meeting, students learned two of four themes. In the third meeting, student learned the rest of themes. Finally, in the last meeting, students were given a posttest, in which the type of this test was similar to that of the pretest. After finishing the posttest, students were asked to fill out short questionnaires. The purpose of the questionnaire was to collect students' responses when using the media.

\section{E. Data analysis}

In this research, we get two types of data. The first type of data is the pretest and posttest data, whereas the other data is from the questionnaire.

For the first type of data, the conventional statistics was used for comparing the results. In simplification, the method was used to get the gain score $(g)$. The calculation used the following calculation:

$$
g=\frac{(y-x)}{(m-x)}
$$

where $y$ and $x$ are the scores of posttest and pretest, respectively. The $m$ is the maximum score, in which this study used 100 for the maximum score. From the calculation, we can conclude that the results are categorized into three zones[12]:

(1) When the value of $g$ is higher than 0.70 , this is classified as "high-g".

(2) When the value of $g$ is between 0.30 and 0.70 , we categorized as "medium- $g$ ".

(3) When the value of $g$ is less than 0.30 , we classified as "lowg".

In addition, to achieve high accuracy of the pretest and the posttest data, we compared the results by analyzing the data using SPSS 16.0 software.

For the second type of data, we get from questionnaires obtained from students. The calculation was based on Likert Scale (for positive statement, the scores are $1=$ Disagree Strongly, 2 = Disagree Slightly, $3=$ Neutral, $4=$ Agree Slightly, 5 = Agree Strongly) [13][14]. Furthermore, the percentage of each statement was interpreted based on Table 1 [14].

TABLE I. QUESTIONNAIRE SCORE (ADOPTED FROM REFERENCE [14])

\begin{tabular}{ll}
\hline Interval of percentage & Category \\
\hline $0 \%-20 \%$ & Very bad \\
\hline $21 \%-40 \%$ & Bad \\
\hline $41 \%-60 \%$ & Enough \\
\hline $61 \%-80 \%$ & Good \\
\hline $81 \%-100 \%$ & Very good \\
\hline
\end{tabular}

\section{RESULTS AND DISCUSSION}

\section{A. Impact of using interactive media on student ability in Japanese language vocabulary}

Gain score analysis showed the value of $g$ was 0.522 (see Table 2). Based on the gain interpretation in this table, the results indicated the increases in gain value. In the other words, the use of interactive media is effective to increase student's vocabulary. In order to support the above result in Table 2, analysis of mean was conducted. The impact of the use of interactive media was known by measuring the change of student's scores. 
TABLE II. GAIN SCORE ANALYSIS RESULTS

\begin{tabular}{|c|c|c|c|}
\hline $\begin{array}{l}\text { Student } \\
\text { sample } \\
\text { number }\end{array}$ & $\begin{array}{c}\text { Pretest } \\
\text { score }(x)\end{array}$ & $\begin{array}{l}\text { Posttest } \\
\text { score }(y)\end{array}$ & Gain $(g)$ \\
\hline $\mathrm{S} 1$ & 63.30 & 70.00 & 0.183 \\
\hline $\mathrm{S} 2$ & 23.30 & 40.00 & 0.218 \\
\hline $\mathrm{S} 3$ & 23.30 & 50.00 & 0.348 \\
\hline $\mathrm{S} 4$ & 56.60 & 63.30 & 0.154 \\
\hline S5 & 33.30 & 50.00 & 0.250 \\
\hline S6 & 76.60 & 93.30 & 0.714 \\
\hline S7 & 76.60 & 90.00 & 0.573 \\
\hline S8 & 76.60 & 96.60 & 0.855 \\
\hline S9 & 26.60 & 63.30 & 0.500 \\
\hline $\mathrm{S} 10$ & 26.60 & 86.60 & 0.818 \\
\hline $\mathrm{S} 11$ & 50.00 & 73.30 & 0.466 \\
\hline $\mathrm{S} 12$ & 70.00 & 93.30 & 0.777 \\
\hline S13 & 23.30 & 60.00 & 0.479 \\
\hline S14 & 76.60 & 100.00 & 1.000 \\
\hline S15 & 73.30 & 86.60 & 0.498 \\
\hline \multicolumn{3}{|c|}{ Average gain } & 0.522 \\
\hline
\end{tabular}

Table 3 showed the means of pretest and posttest scores by student (calculated by SPSS software). The result showed a change in student's ability. The score of posttest were higher than that of pretest in all of students. This indicates the use of interactive media gives positive impact on students' ability in learning Japanese language vocabulary.

TABLE III. THE SPSS RESULTS ON THE MEANS OF PRETEST AND POSTTEST SCORES

\begin{tabular}{lll}
\hline & \multicolumn{1}{c}{ Pretest } & Posttest \\
\hline $\mathrm{N}$ valid & 15 & 15 \\
\hline $\mathrm{N}$ missing & 0 & 0 \\
\hline Mean & 51.733 & 74.420 \\
\hline Standard deviation & 23.085 & $\frac{19.368}{375.149}$ \\
\hline Variance & 532.942 &
\end{tabular}

Table 4 shows the SPSS result on the coefficient of correlation. The value of the coefficient of correlation is 0.808 . This result indicates that the correlation between two factors is very strong [14]. The tendency of the result in this table was almost the same with the above result in Table 3, offering the effectiveness of the present media for improving student ability to remembering vocabulary.
TABLE IV. THE SPSS RESULTS ON THE COEFFICIENT OF CORRELATION

\begin{tabular}{lll}
\hline & \multicolumn{1}{c}{ Pretest } & Posttest \\
\hline Pretest & 1 & 0.808 \\
Pearson correlation & & 0.000 \\
Sig. (2-tailed) & 15 & 15 \\
N & & \\
\hline Posttest & 1 \\
Pearson correlation & 0.808 & \\
Sig. (2-tailed) & 0.000 & 15 \\
N & 15 & \\
\hline
\end{tabular}

\section{B. Student responses on using of interactive media}

The questionnaire contains of five statements related to the appearance and the function in the media (Table 5). Based on the questionnaire result, the percentage of students' responses in each statement was categorized as "good" (more than 61\%). It indicates that this media can be categorized attractive and easy to be used. The content and features provided also are useful for improving students' ability on Japanese language vocabulary.

TABLE V. THE QUESTIONER RESULTS

\begin{tabular}{lc}
\hline \multicolumn{1}{c}{ Statements } & Percentage of responses \\
\hline The media is attractive & $82,67 \%$ \\
\hline $\begin{array}{l}\text { The media is easy to use } \\
\text { The media provide additional Japanese }\end{array}$ & $69,33 \%$ \\
$\begin{array}{l}\text { Language vocabulary } \\
\text { The content of matter can help to improve the } \\
\text { ability on vocabulary }\end{array}$ & $90,67 \%$ \\
\hline Additional features provided are useful & $92,00 \%$ \\
\hline
\end{tabular}

\section{CONCLUSION}

We developed a method for improving student ability for learning Japanese language vocabulary. The study was also completed with pretest, posttest, and questionnaire. The results of pretest and posttest confirmed that the media is effective to improve the student ability for remembering Japanese language vocabulary. The questionnaires showed positive responses from the students, confirming that the media was attractive, easy to be used, and useful for remembering Japanese language vocabulary.

\section{ACKNOWLEDGMENT}

R.S.R. thanks to Soni Mulyawan S., M.Pd. for his assistance, consultation, and discussion in this research.

\section{REFERENCES}

[1] R.Camilie 2013 Languge Use in the United States:2011 (Suitland:U.S Census Bureau)

[2] Australian Curriculum Assesment and Reporting Authority (ACARA) 1968 Australian Curriculum:Languages (Sydney:ACARA)

[3] R. Oxfod and J. Shearin 1991 Language learning motivation: Expanding the theoritical framework The Modern Languge Journal 78 12-28 
[4] R. Oxfod and J. Shearin 1991 Language learning motivation: Expanding the theoritical framework The Modern Languge Journal 78 12-28

[5] J. Read 2000 Assessing Vocabulary (Cambridge: Cambridge University)

[6] Y. Okuyama 2007 CALL Vocabulary Leraning in Japanes: Does Romaji Help Beginners Learn More Words? CALICO Journal 24 355-379

[7] M.Kireeva 2014 Methods of Teaching Basic Japanese Course to the First Year Student: Proc. Of Methods of Teaching Oriental Languages: Actual prblems and Trends (Moskow, Russia,May 14-15 2014) 1-18

[8] A.Sasadhara, N.S.Sasanti 2013 Media Picture and Picture for The Mastery of Japanese Language Vocabulary HIKARI. 11

[9] P.M Primayanti, I.N.P.H Saputra, P.D.M.Y Pramesti 2014 Development of Learning Media Japanese Vocabulary Smart Card for Begineer Class Online Journal of Pendidikan Bahasa Jepang Universitas Pendidikan Ganesha. 11
[10] N.W Suwitri, I.N.P.H Saputra, K.D.K Adnyani 2015 Development of Learning Media Japanese Vocabulary Kuartet Card for Student in Class X SMA Negeri 1 Sawan Online Journal of Pendidikan Bahasa Jepang Universitas Pendidikan Ganesha. 11

[11] D.M. Dimitrov, P.D Rumrill 2003 Pretest-Postest Design and Measurement of Change Work 20 159-165

[12] R.R.Hake 1999 Analyzing Change/Gain Score (California: American Educational Research Association's Division D)

[13] J.B Sexton, R.L. Helmreich, T.B. Neilnads, K.Rowan, K.Vella, J.Byden, P.R Roberts, and E.J Thomas 2006 The Safety Attitudes Questionnare: Psychometric Properties, Benchmarking Data, and Emerging Research BMC Health Service Research 6 1-10

[14] Sugiyono 2007 Bussiness Research Method (Bandung:Alfabeta) 